\title{
Comparison of methodologies for moisture determination on dried bee pollen samples
} Comparação de metodologias para determinação de umidade em amostras de pólen apícola desidratadas

\author{
Illana Louise Pereira de MELO ${ }^{1}$, Ligia Bicudo de ALMEIDA-MURADIAN ${ }^{1 *}$
}

\begin{abstract}
Bee pollen moisture value is one of the quality parameters for this product. Some countries such as Argentina, Brazil, Bulgaria, Poland and Switzerland have bee pollen regulations on quality parameters, but these are not clear regarding which method should be used for moisture determination. The aim of this paper was to compare six methods of moisture determination in dried bee pollen samples. The methods were: conventional oven at $100^{\circ} \mathrm{C}$, vacuum oven at $70^{\circ} \mathrm{C}$, desiccator with sulfuric acid, drying out process with infrared light at $85^{\circ} \mathrm{C}$, lyophilization and Karl Fisher's method. Based on the results, the best methods for moisture determination of bee pollen were the drying process with infrared and the lyophilization, since these have shown lower moisture values.
\end{abstract}

Keywords: bee pollen; moisture; methods.

\section{Resumo}

O teor de umidade do pólen apícola constitui um parâmetro de qualidade para este produto. Alguns países como Argentina, Brasil, Bulgária, Polônia e Suíça têm legislação específica quanto aos parâmetros de qualidade do pólen apícola, mas não são claras quanto à recomendação do método a ser utilizado na determinação de umidade. O objetivo deste trabalho foi comparar seis métodos de determinação de umidade do pólen apícola desidratado. Os métodos utilizados foram: estufa convencional a $100^{\circ} \mathrm{C}$, estufa a vácuo a $70^{\circ} \mathrm{C}$, dessecador com ácido sulfúrico, secagem por radiação infravermelha, liofilização e Karl Fisher. De acordo com os resultados obtidos, os melhores métodos para determinação de umidade do pólen apícola foram a secagem por radiação infravermelha e a liofilização, os quais apresentaram menores valores de umidade. Palavras-chave: pólen apícola; umidade; métodos.

\section{Introduction}

Pollen grains are microscopic structures found in the anthers of stamens in angiosperms and represent the male gametophyte of flowers. Besides being the very object of pollination, for many insects and especially to bees, pollen is the main source of food, essential for normal growth and development of all individuals of a colony of bees and to the reproduction of colonies (KRELL, 1996; ALMEIDA-MURADIAN et al., 2007; CAMPOS et al., 2008).

Pollen is very important in apiculture as a natural source of proteins, fats, minerals and vitamins to bees and as a product surplus from apiary (WITHERELL, 1975; HERBERT JR.; SHIMANUKI, 1978; VILLANUEVA et al., 2002). According to the Normative Instruction $\mathrm{N}^{\circ} 3$ from the Brazilian regulation, January 19, 2001 (BRASIL, 2001), bee pollen is the result of the agglutination of flower pollens, carried out by worker honey bees, with nectar (and/or honey) and salivary substances, and collected at the hive entrance. This definition has also been reported by Campos et al. (2008) when an international technical regulation for identity and quality of bee pollen standard was proposed.

The concern of consumers in developed countries with food quality and, consequently, the reduction of risks to health, is growing. In this sense, bee pollen has prominence in human nutrition as a food differential due to its nutritious and medicinal properties and also because of its high protein content (VILLANUEVA et al., 2002; MARCHINI; REIS; MORETI, 2006).

According to the technical regulations proposed by Campos et al. (2008), bee pollen can be classified according to its moisture content for commercialization purposes. Bee pollen is the product collected in the original form, with water content between $20-30 \%$, and dried bee pollen is the product submitted to a drying process at temperatures not higher than $42{ }^{\circ} \mathrm{C}$, with water content not higher than $6 \%$. Because bee pollen displays high moisture content in its composition, which causes fermentation and rapid deterioration (HERBERT JR.; SHIMANUKI, 1978; CORNEJO, 1994), a drying out process is essential. Moisture content is used for biological control in storage and commercialization of the product, since water content affects - via water activity - enzymatic and microbiological stability and, thus, shelf life of food (SILVA et al., 2001; ISENGARD; KLING; REH, 2006).

Some countries have established official quality and identity standards of bee pollen such as: Argentina (CÓDIGO ALIMENTARIO Argentino de pólen, Artículo 785 - Resolucion 1550 de 12/12/1990), Brazil (BRASIL, 2001), Bulgaria

Recebido para publicação em 13/4/2009

Aceito para publicação em 25/9/2009 (004159)

${ }^{1}$ Food Department, Pharmaceutical Science School, University of Sao Paulo - USP, Av. Prof. Lineu Prestes, 580, Bloco 14, CEP 05508-900, São Paulo - SP, Brasil,

E-mails: illanalpm@usp.br; ligiabi@usp.br

${ }^{*}$ A quem a correspondência deve ser enviada 
(BULGARIAN STANDARD 2567111-91 apud CAMPOS et al., 2008), Poland (PN-R-78893 “Obnóza pylkowe”- POLISH LEGISLATION FOR BEE-POLLEN apud CAMPOS et al., 2008) and Switzerland (BOGDANOV et al., 2004). These countries have established minimal requirements for dried pollen: Argentina (max. 8\%), Brazil: (max. 4\%), Bulgaria (max. 10\%), Poland (max. 6\%), and Switzerland (max. 6\%).

As bee pollen moisture content is a parameter of quality for this product, its determination is one of the most important measures of analysis. It is also related to the stability, quality and composition of foods (GARCIA-AMOEDO; ALMEIDAMURADIAN, 2002; CECCHI, 2003). Nevertheless, the regulations on the quality of bee pollen do not have clear recommendations for procedures on how to be used, citing official analytical methods for control of animal products. According to Serra-Bonvehi and Casanova (1987), the pollen moisture has been measured by various methods, which lead to very divergent results. For this reason, it is important to have a study of methodologies comparison for dried bee pollen moisture determination in order to contribute with the standardization of methods applied to the quality control of bee pollen. The aim of this paper was to compare six methods of moisture determination on dried bee pollen samples.

\section{Materials and methods}

\subsection{Materials}

Six commercial samples of newly collected dried bee pollen batches were acquired from different Brazilian bee products warehouses. The batches were identified with numbers from one to six and were kept frozen in their original bags until the moisture was determined.

\subsection{Methods}

\section{Moisture determination}

Dried bee pollen's moisture determination was made by gravimetry methods, based on the sample weight loss due to desiccation, until constant weight was reached (from I to V) and by volumetric method (VI):

I Drying using conventional oven at $100{ }^{\circ} \mathrm{C}\left(\right.$ FANEM $^{\circledast}$, Brazil);

II Drying using vacuum oven at $70^{\circ} \mathrm{C}\left(\right.$ FANEM $^{\circledR}$, Brazil);

III Drying in an environment with low water activity, using desiccator with sulfuric acid in oven at $40{ }^{\circ} \mathrm{C}$;

IV Drying under infra-red radiation, in equipment composed of electronic precision balance Micronal (B160), adapted with infra-red dryer Mettler Toledo (LP16), with adjustments to the intensity of radiation emitted, so that the sample reaches $85^{\circ} \mathrm{C}$;

$\mathrm{V}$ Lyophilization, using equipment of the brand Edwards , model EC Super Modulyo, at the temperature of $-40^{\circ} \mathrm{C}$ for 26 hours and final vacuum inferior to $4 \times 10^{-1}$ Torr, in accordance with the standards of the manufacturer.
VI Karl Fischer's method, using the apparatus of Mettler Toledo (DL38) based on the amount of reagent of Karl Fischer (with its correction factor) required to hold the water in the rate of the sample tested.

The methods described in items I, II, III, IV and VI followed the procedure described by Serra-Bonvehi and Casanova (1987). The methods I, II and III are also listed by AOAC (ASSOCIATION..., 1995). The process of lyophilization was based on the work of Liapis, Millman and Marchello (1985) and Boss (2004).

In all cases, samples were ground to better homogenization of the batches and a rate of each of the samples (approximately $2 \mathrm{~g}$, except method IV which used approximately $1 \mathrm{~g}$ ) was submitted to the process. All batches were analyzed in triplicate, except for the Karl Fischer's, which was made in two duplicates.

Moisture content of samples submitted to processes I, II, III and $\mathrm{V}$ up to constant weight was calculated using the Equation 1:

$\%$ moisture $=100-\left[\left(\frac{\left(m^{\prime}-t\right)}{(m-t)}\right) \times 100\right]$

where:

$\mathrm{m}=$ total mass of the system (glass + sample) at the beginning of the process;

$\mathrm{m}^{\prime}=$ total mass of the system (glass + sample) at the end of the process;

$\mathrm{t}=$ mass of glass used.

For the analysis that used infrared radiation, a rate of the sample was applied to a holder (small aluminum plate) previously weighed, according to Cornejo (1994) and Oliveira (2006). After that, radiation was reflected on the sample and the percentage of moisture was displayed on the equipment. The determination of moisture by the volumetric method was based on aquametria with reagent "Karl Fischer". The moisture content was estimated based on the amount of reagent (with its correction factor) required to hold the water in the rate of the sample tested. The calculation was made using the Equation 2:

$\%$ moisture $=\left[\frac{(v \times c f)}{S A T}\right] \times 100$

where:

$\mathrm{v}=$ volume of Karl Fischer's reagent required for sample titration; $\mathrm{cf}=$ correction factor, the equivalent in water that can be neutralized by Karl Fischer's reagent;

$\mathrm{SAT}=$ sample aliquot tested

\section{Statistical analysis}

The results were statistically evaluated using variance analysis (ANOVA one-way) followed by Tukey's test for significance $\mathrm{p}<0.05$. The statistical software used was Statistica (data analysis software system) (2007), version \#8. 


\section{Results and discussion}

The pollen samples were compared using six different methods for moisture analysis and the results are shown in Table 1.

In Figure 1 are the moisture average values of the samples for various methods used.

It can be observed that, in general, in the processes in which heat is used ( 1 and 2), the moisture values are higher than in other cases, except for samples exposed to infrared radiation (3), where there is heat application, but only for a short time.

According to the indication of statistical analysis, the method that employs infrared radiation is equivalent to the lyophilization method and it obtained the lowest moisture values when compared to other methods. With respect to infrared method, it has the advantage of being faster and it could be more advantageous for the analysis of quality control of a well-equipped laboratory, where the amount of samples is generally large. According to Cecchi (2003), drying through infrared radiation is more effective that drying in oven and involves penetration of heat inside the sample, shortening the drying period. This method, while exposing the samples to an increase in temperature, does it for short periods only. This could contribute to the integrality of the samples (GARCIAAMOEDO; ALMEIDA-MURADIAN, 2002).

Serra-Bonvehi and Casanova (1987), in studying methods of bee pollen moisture analysis from Spain, obtained the following average values: $13.4 \%$ for oven at $110-105{ }^{\circ} \mathrm{C}(\mathrm{n}=31) ; 5.9 \%$ for vacuum oven at $65{ }^{\circ} \mathrm{C}(\mathrm{n}=31) ; 4.7 \%$ for the Karl Fischer's method $(n=3) ; 5.2 \%$ for radiation Infra-red $(n=3)$. Their conclusion considered the Karl Fischer's and the vacuum oven as the most appropriate methods for pollen moisture analysis, and Infra-red as optional. Isengard, Kling and Reh (2006) proposed Karl Fischer's titration as the standard and reference method for determination of water content in dried dairy products. Silva et al. (2001), on the other hand, when testing three methods of moisture analysis of powder dust and meal of algaroba, observed equivalence between the conventional method (oven at $100{ }^{\circ} \mathrm{C}$ ) and the infrared radiation; this probably occurred because of the characteristic of the sample, which is subject to prior drying with high temperatures for obtaining powder.
The regulations for the identity and quality of bee pollen proposed by various countries do not give clear recommendations on which procedures to be used in moisture measuring, citing official analytical methods for control of animal products. One method of analysis for dried samples (ASSOCIATION..., 1995), recommends submitting an approximately $2 \mathrm{~g}$ sample at 95$100{ }^{\circ} \mathrm{C}$ until constant weight. In Brazil, there is the analytical standards of Adolfo Lutz Institute (Brazilian official laboratory from the Health Ministry), referring to direct heating of the sample in an oven at $105{ }^{\circ} \mathrm{C}$ as the most widely used for the analysis of food in general (INSTITUTO ADOLFO LUTZ, 2005).

Under the terms of the conventional method (oven at $105^{\circ} \mathrm{C}$ ), the results showed dark-brown color in samples at the end of the process, which are a characteristic of darkening reactions. These characteristics were also observed, but to a lesser extent, in the method of the vacuum oven at $70{ }^{\circ} \mathrm{C}$. It is believed that this characteristic is due to the occurrence of the Maillard reaction. Moreover, the moisture values observed in

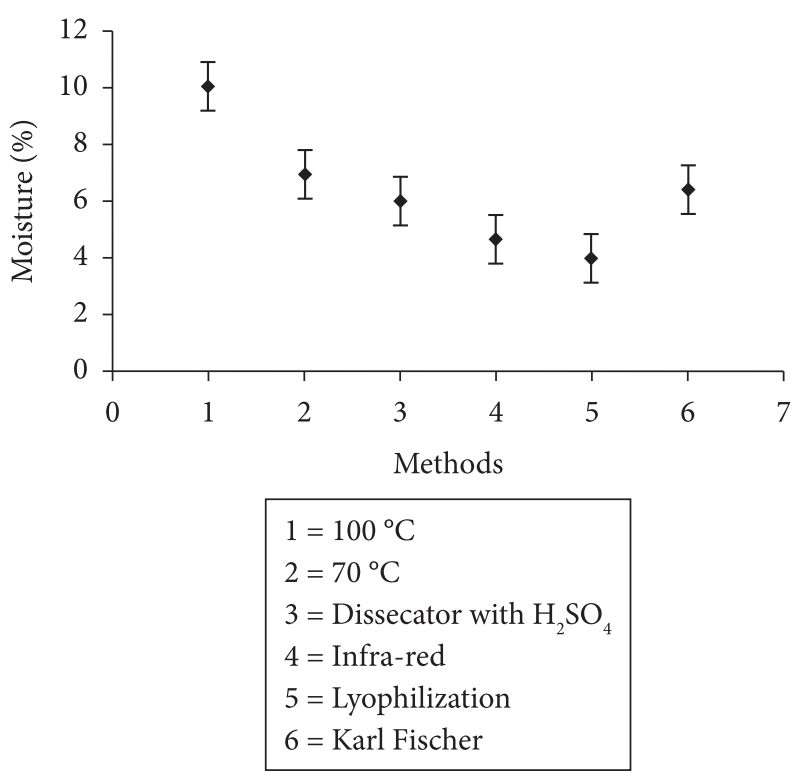

Figure 1. Moisture average values found in dried bee pollen samples according to six different methods.

Table 1. Moisture content of dried bee pollen samples through six different methods.

\begin{tabular}{ccccccc}
\hline \multirow{2}{*}{ Batches } & \multicolumn{5}{c}{${\text { Moisture }(\%)^{*}}^{*}$} \\
\cline { 2 - 7 } & $100{ }^{\circ} \mathrm{C}$ & $70^{\circ} \mathrm{C}($ vacuum $)$ & $\mathrm{H}_{2} \mathrm{SO}_{4}$ & Infra-red & Lyophilization & Karl Fischer's \\
\hline 1 & $11.54 \pm 0.46$ & $6.61 \pm 0.07$ & $6.02 \pm 0.09$ & $4.44 \pm 0.02$ & $4.24 \pm 0.09$ & 4.48 \\
2 & $10.61 \pm 0.32$ & $7.60 \pm 0.10$ & $7.32 \pm 0.05$ & $4.85 \pm 0.05$ & $5.30 \pm 0.11$ & 5.87 \\
3 & $9.69 \pm 0.15$ & $7.03 \pm 0.07$ & $6.55 \pm 0.06$ & $4.57 \pm 0.05$ & $4.55 \pm 0.11$ & 6.92 \\
4 & $11.82 \pm 0.37$ & $7.83 \pm 0.07$ & $6.71 \pm 0.03$ & $5.84 \pm 0.03$ & $4.20 \pm 0.11$ & 6.08 \\
5 & $9.19 \pm 0.02$ & $6.40 \pm 0.07$ & $4.72 \pm 0.09$ & $3.72 \pm 0.05$ & $2.65 \pm 0.15$ & 9.27 \\
6 & $7.28 \pm 0.10$ & $6.13 \pm 0.20$ & $4.58 \pm 0.09$ & $4.57 \pm 0.02$ & $2.80 \pm 0.05$ & 5.78 \\
Média & $10.02^{\mathrm{a}}$ & $6.93^{\mathrm{b}}$ & $5.98^{\mathrm{c}}$ & $4.67^{\mathrm{d}}$ & $3.96^{\mathrm{d}}$ & $6.40^{\mathrm{b}, \mathrm{c}}$ \\
\hline
\end{tabular}

${ }^{*}$ Results expressed in average \pm standard deviation of analysis in triplicate, except for Karl Fischer's method, which was performed in duplicate. Different letters indicate statistical differences between methods of moisture analysis, according to the Tukey's test $(\mathrm{p}<0.05)$. 
these methods are larger and could be due to loss of volatile compounds, besides water, during heating. These events were also observed by Garcia-Amoedo and Almeida-Muradian (2002), who analyzed royal jelly samples through different drying methods. According to Cecchi (2003), in the event of evaporation in oven at $100^{\circ} \mathrm{C}$ until constant weight, a moisture overestimation can occur due to loss of volatile substances or decomposition reactions. Serra-Bonvehi and Casanova (1987), in analyzing pollen samples subjected to different drying methods, found that, in conventional oven at $105-110^{\circ} \mathrm{C}$, they had a greater loss of glucose, fructose and $\alpha$-free amino acids, when compared to other drying methods.

\section{Conclusion}

From all the obtained results, it can be concluded that the drying by infra-red radiation and the lyophilization were the best methods for bee pollen moisture analysis.

\section{Acknowledgements}

The "Conselho Nacional de Desenvolvimento Científico e Tecnológico" - CNPq (National Council for Scientific and Technological Development) for the granted scholarships and to "Fundação de Amparo à Pesquisa do Estado de São Paulo" FAPESP - Process No. 06/59187-9 (Foundation of Support for Research of the State of Sao Paulo) for the financial support.

\section{References}

ALMEIDA-MURADIAN, L. B. et al. Produtos Apícolas. In: ALMEIDAMURADIAN, L. B.; PENTEADO, M. D. V. C. (Eds.). Vigilância sanitária: tópicos sobre legislação e análise de alimentos. Rio de Janeiro: Guanabara Koogan, 2007. cap. 10. p. 183-198.

ARGENTINA. Ministerio de Salud. Administración Nacional de Medicamentos, Alimentos y Tecnologia Médica. Código Alimentario Argentino de Pólen. Artículo 785 - Resolucion 1550 de 12 de dezembro de 1990. cap. X, p. 15.

ASSOCIATION OF OFFICIAL ANALYTICAL CHEMISTS - AOAC. Official methods of analysis. $16^{\text {th }} \mathrm{ed}$. Washington, 1995.

BOGDANOV, S. et al. Swiss Food Manual. Bienenprodukte: Pollen, BAG (Swiss Federal Office for Public Health), Berne, 2004. cap. 23 B.

BOSS, E. A. Modelagem e otimização do processo de liofilização: aplicação para leite desnatado e café solúvel. 2004. 129 f. Tese (Doutorado em Engenharia Quimica)-Faculdade de Engenharia Química, Universidade Estadual de Campinas, Campinas, 2004.

BRASIL. Instrução Normativa n. 3, de 19 de janeiro de 2001. Regulamentos Técnicos de Identidade e Qualidade de Apitoxina, Cera de Abelha, Geléia Real, Geléia Real Liofilizada, Pólen Apícola, Própolis e Extrato de Própolis. Diário Oficial [da]
República Federativa do Brasil, Brasília, DF, 19 jan. 2001. Disponível em: <http://e-legis.bvs.br/leisref/public/showAct. php?id=12479\&word $>$. Acesso em: 09 out. 2007.

CAMPOS, M. G. R. et al. Pollen composition and standardisation of analytical methods. Journal of Apicultural Research and Bee World, v. 47, n. 2, p. 156-163, 2008.

CECCHI, H. M. Fundamentos teóricos e práticos em análise de alimentos. $2^{\circ} \mathrm{ed}$. Campinas: UNICAMP, 2003.

CORNEJO, L. G. Pólen: tecnologia de su produccion, procesado, y comercializacion. Buenos Aires: IPTEA, 1994.

GARCIA-AMOEDO, L. H.; ALMEIDA-MURADIAN, L. B. Comparação de metodologias para a determinação de umidade em geléia real. Química Nova, v. 25, n. 4, p. 676-679, 2002.

HERBERT JR., E. W.; SHIMANUKI, H. Chemical composition and nutritive value of bee-collected and bee-stored pollen. Apidologie, v. 9, n. 1, p. 33-40, 1978.

INSTITUTO ADOLFO LUTZ. Métodos físico-químicos para análise de alimentos. 4. ed. Brasília: Ministry of Health, 2005.

ISENGARD, H. D.; KLING, R.; REH, C. T. Proposal of a new reference method to determine the water content of dried dairy products. Food Chemistry, v. 96, p. 418-422, 2006.

KRELL, R. Value-added products from beekeeping. FAO Agricultural Services Bulletin, 1996. v. 124, p. 87-113.

LIAPIS, A. I.; MILLMAN, M. J.; MARCHELLO, J. M. An analysis of the lyophilization process using a sorption-sublimation model and various operational policies. American Institute of Chemical Engineers Journal, v. 31, n. 10, p. 1594-1604, 1985.

MARCHINI, L. C; REIS, V. D. A.; MORETI, A. C. C. C. Composição físico-química de amostras de pólen coletado por abelhas Africanizadas Apis mellifera (Hymenoptera:Apidae) em Piracicaba, estado de São Paulo. Ciência Rural, v. 36, n. 3, p. 949-953, 2006.

OLIVEIRA, K. C. L. S. Caracterização do pólen apícola e utilização de vitaminas antioxidantes como indicadoras do processo de desidratação. 2006. 106 f. Dissertação (Mestrado em Ciência dos Alimentos)-Faculdade de Ciências Farmacêuticas, Universidade de São Paulo, São Paulo, 2006.

SERRA-BONVEHI, J.; CASANOVA, T. M. Estudio analitico para determinar la humedad del polen. Analytical Bromatology, v. 34, n. 2, p. 339-349, 1987.

SILVA, S. A. et al. Estudo termogravimétrico e calorimétrico da algaroba. Química Nova, v. 24, n. 4, p. 460-464, 2001.

STATISTICA 8.0 for Windows, v. 1. Tulsa: StatSoft Inc. Software,2007.

VILLANUEVA, M. T. O. et al. The importance of bee-collected pollen in the diet: a study of its composition. International Journal of Food Sciences and Nutrition, v. 53, n. 3, p. 217-224, 2002.

WITHERELL, P. C. Otros productos de la colmena. In: DADANT, E. (Ed.) La colmena y la abeja mellifera. Montevideo: Hemisferio Sur, 1975. 